\title{
Pelatihan dan Pendampingan Kecakapan Hidup Berbasis Desain Grafis Bagi Anak Didik Lembaga Pembinaan Khusus Anak
}

\author{
Febrianty $^{1}$, Fatmariani $^{2}$, Hendra Rotama ${ }^{3}$ \\ Politeknik Palcomtech
}

Korespondensi: febrianty@palcomtech.ac.id

Diserahkan: 15 Juli 2018, Direvisi: 5 Agustus 2018, Diterima: 15 Agustus 2018

\begin{abstract}
Community Partnership Program Activities (PKM) conducted by the author in the form of technopreneurship-based life skills training and mentoring in the field of graphic design for students at the Palembang Class I Child Special Development Institution (LPKA). Partners This program is the Education and Skills Field (Partner I) and the Field of Community Guidance and Child Alleviation (Partner 2) in LPKA Class I Palembang. The activities carried out by the writing team in the form of training and mentoring were carried out for 8 months, with the implementation method consisting of 5 stages, namely: preparation, coaching, mentoring, training and evaluation of activities. From the results of the activity there was an increase in competitiveness of $60 \%$, the ability to apply Science and technology in the field of graphic design with an achievement of 78\%, and an increase in students' self-confidence and independence of students with special skills possessed as well as entrepreneurial spirit in the field of Graphic Design with achievements 64\%. Keywords: PKM, LPKA, technopreneurship, graphic design
\end{abstract}

\begin{abstract}
Abstrak
Kegiatan Program Kemitraan Masyarakat (PKM) yang dilakukan penulis berupa pelatihan dan pendampingan kecakapan hidup berbasis technopreneurship bidang desain grafis bagi Anak Didik di Lembaga Pembinaan Khusus Anak (LPKA) Kelas I Palembang. Mitra Program ini adalah Bidang Pendidikan dan Keterampilan (Mitra I) dan Bidang Bimbingan Kemasyarakatan dan Pengentasan Anak (Mitra 2) di LPKA Kelas I Palembang. Kegiatan yang dilakukan oleh tim penulis berupa pelatihan dan pendampingan dilaksanakan selama 8 bulan, dengan metode pelaksanaan terdiri dari 5 tahap, yakni: persiapan, pembinaan, pendampingan, pelatihan dan evaluasi kegiatan. Dari hasil kegiatan terjadi peningkatan daya saing 60\%, kemampuan penerapan Ilmu Pengetahuan dan teknologi bidang desain grafis dengan capaian sebesar $78 \%$, dan terjadi peningkatan rasa percaya diri anak didik dan kemandirian anak didik dengan keterampilan khusus yang dimiliki serta semangat kewirausahaan bidang Desain Grafis dengan capaian 64\%.

Kata Kunci : PKM, LPKA, technopreneurship, desain grafis
\end{abstract}

\section{A. PENDAhuluan}

\section{Latar Belakang}

Lembaga Pembinaan Khusus Anak (LPKA) Kelas I Palembang adalah LPKA percontohan di Indonesia yang berhasil menerapkan sekolah kelas jauh/filial dengan standar yang sama dengan sekolah pengelola teknis pembelajarannya (sekolah induk) bekerjasama dengan Dinas Pendidikan Kota Palembang, Pemerintah Kota Palembang dan Pemerintah Provinsi Sumatera Selatan. LPKA Kelas I Palembang menyelenggarakan pendidikan formal mulai dari Sekolah Dasar (SD), Sekolah Menengah Pertama (SMP) dan Sekolah Menengah Atas (SMA) dengan ruang belajar yang representatif sebagai pemenuhan hak pendidikan bagi anak LPKA untuk belajar. Pola pembinaan yang inklusif yakni berupaya mendidik anak LPKA untuk mempunyai kesempatan yang sama dalam berkarya dan bercita-cita serta mengembangkan potensi diri.

LPKA juga telah berhasil mengubah nuansa Lembaga Pemasyarakatan (lapas) menjadi Lembaga Pembinaan yang layak untuk usia anak dengan mengubah ruangan dan bentuk serta menyediakan fasilitas yang nayaman bagi anak didik LPKA Kelas I Palembang. LPKA Kelas I Palembang pada dasarnya tidak berbeda dengan lapas lain pada umumnya. Dasar Yuridis 
Operasional sama-sama menganut Undang-undang No. 12 Tahun 1995 tentang Pemasyarakatan. Salah satu konsep yang sama dilihat dari tujuan akhir, dimana pembinaan, pelatihan, dan pembimbingan terhadap warga binaan sama dengan terhadap anak didik yang dilaksanakan di LPKA Kelas I Palembang yakni: mengarah pada penyatuan (integrasi) kehidupan di dalam masyarakat. Oleh karenanya pelaksanaan pembinaan, pelatihan, dan pembimbingan, dan hal-hal lain yang menyangkut masalah hidup, perikehidupan, dan penghidupan warga binaan/anak didik harus memenuhi prinsip-prinsip dasar yang termaktub dalam Undang-undang No.12 Tahun 1995, antara lain: Pengayoman, persamaan harkat dan martabat manusia, kehilangan kemerdekaan merupakan satu-satunya penderitaan, terjaminnya hak untuk tetap berhubungan dengan keluarga dan orang tertentu. Implementasi dari prinsipprinsip yang harus diterapkan, maka perikehidupan lapas harus senantiasa: menjunjung tinggi hak-hak warga binaan/anak didik, bersikap welas asih, tidak menyakiti, perlakuan adil, menjaga rahasia, memperhatikan pengaduan dan keluhan, memberikan rasa keadilan masyarakat, menjaga kehormatan dan menjadi teladan, sopan dan tegas dalam pelaksanaan pembinaan. Menurut Undang-undang No. 12 Tahun 1995 tentang Pemasyarakatan dalam rangka pembinaan dan terhadap narapidana di Lembaga Pemasyarakatan sebaiknya dilakukan penggolongan atas dasar : Umur, Jenis Kelamin, Lama Pidana yang Dijatuhkan, Jenis kejahatan, dan kriteria lainnya sesuai dengan kebutuhan/perkembangan pembinaan. Anak didik LPKA Kelas I Palembang Tahun 2016 berjumlah 147 orang. Kegiatan yang dilakukan di LPKA beberapa diantaranya adalah karate, pramuka, pelatihan baris berbaris, pengajian, menyanyi, memainkan alat musik, bola voli, dan futsal. Saat ini pembinaan keterampilan yang dilakukan hanya keterampilan berkebun, pertukangan, perikanan, pangkas rambut, las listrik, pelatihan komputer dasar, dan kerajinan tangan.

Walaupun menjadi LPKA yang cukup berprestasi dan inovatif, akan tetapi pihak mitra tetap memiliki keterbatasan dalam penyelenggaraan program pembinaan. Program pembinaan keterampilan yang diadakan oleh LPKA kurang antusias diikuti oleh anak didik karena keterbatasan program atau program yang belum sesuai dengan keinginan/minat anak didik. Sebagian anak didik mengikuti program pembinaan keterampilan dengan unsur terpaksa sehingga anak didik sulit memahami maksud dari program tersebut dan hasil pembinaan tidak sesuai dengan yang diharapkan. Masih ada anak didik yang sudah habis masa pidannya kembali melakukan tindak pidana dengan alasan ekonomi dan kesulitan mencari kerja. Anak didik LPKA masih memiliki sikap yang pesimis, apatis, dan kurang percaya diri. Disamping itu, latar belakang pendidikan dan perekonomian keluarga yang kurang, turut menjadikan anak didik bersikap malas dan tidak peduli dengan masa depannya. Hal tersebut menyebabkan kedua pihak mitra kesulitan untuk memberikan dan mensinergikan program pembinaan baik itu pembinaan kepribadian maupun pembinaan kemandirian yang dapat membekali anak didik. Apalagi belum pernah ada sebelumnya program kecakapan hidup yang berbasis technopreneuship bagi anak didik LPKA Kelas I Palembang.

\section{Profil Mitra}

Mitra yang terlibat dalam kegiatan Program Kemitraan Masyarakat ini adalah LPKA Kelas I Palembang yaitu Bidang Pendidikan dan Pelatihan Keterampilan (mitra satu) dan Bidang Bimbingan Kemasyarakatan dan Pengentasan Anak (Mitra dua). Bidang Pendidikan dan Keterampilan yang dipimpin oleh Bapak Fahriyuddin Jusep, S.Ag. (Mitra I), memiliki tugas pelayanan pendidikan bagi anak didik dan menyelenggarakan kegiatan-kegiatan pelatihan yang dapat meningkatkan potensi diri, berkarya dan berusaha. Sedangkan Bidang Bimbingan Kemasyarakatan dan Pengentasan Anak yang dipimpin oleh Bapak Hendri, S.H. (Mitra 2), memiliki tugas utama membekali anak didik kembali ke masyarakat dengan bekal perilaku dan pengetahuan yang dapat diterima masyarakat dan lingkungannya. Mitra satu 
menekankan pembekalan pada anak didik yang masa pidananya lebih lama (lebih dari satu tahun) sedangkan mitra dua menekankan pembinaan pada anak didik yang memiliki pidana yang singkat.

Mitra 1 menekankan pembekalan pada anak didik yang masa pidananya lebih lama (lebih dari satu tahun) sedangkan mitra 2 menekankan pembinaan pada anak didik yang memiliki pidana yang singkat. Dari 173 orang anak didik (data Bulan April 2017), yang menjadi target bagi mitra 1 adalah sebanyak 75 anak didik sedangkan yang menjadi target bagi mitra 2 adalah sebanyak 88 anak didik.

Berdasarkan hasil observasi dan wawancara awal terhadap kedua mitra sasaran dapat diidentifikasi permasalahan yaitu: 1) Pihak mitra belum pernah memberikan program kecakapan hidup (life skill) bagi anak didik di bidang IT, 2) Pihak mitra sampai saat ini belum memiliki SDM dengan kompetensi IT untuk memberikan pembekalan keterampilan bidang IT, 3) Pihak mitra mengandalkan peran dari pihak luar/para sukarelawan untuk kegiatan pelatihan keterampilan IT, 4) Rendahnya jiwa technopreneur anak didik, 5) Materi-materi dalam program pendidikan dan pelatihan keterampilan yang diadakan mitra kurang antusias diikuti oleh anak didik, 6) Laboratorium komputer LPKA belum digunakan maksimal, 7) Belum ada pembekalan khusus yang dilakukan oleh pihak Mitra yang terprogram yang mengarah ke pembekalan keterampilan bidang IT, sehingga masih ada anak didik yang sudah habis masa pidananya kembali melakukan tindak pidana karena alasan ekonomi dan kesulitan mencari pekerjaan serta tidak memiliki skill yang memadai atau tidak mampu menciptakan lapangan kerja sendiri, 8) Mitra dua khususnya mengalami kesulitan dalam meningkatkan rasa percaya diri anak didik untuk mempersiapkan mereka kembali ke masyarakat, 9) Mitra mengalami kesulitan karena belum ada hasil berupa produk dari program pelatihan keterampilan yang dapat dipasarkan atau dipamerkan secara representatif saat ada acara/event.

\section{B. TINJAUAN PUSTAKA}

Kenakalan anak dan remaja adalah salah satu masalah yang tengah dihadapi Indonesia.Jumlah kejadian dan kualitas kenakalannya terus meningkat hingga menjurus pada tindak kriminalitas yang menyebabkan pelakunya terkena masalah hukum (Atikasuri, M., Mediani, H. S., \& Fitria, N, 2018). Apabila pelaku yang terkena masalah hukum diputuskan oleh pengadilan untuk menjalani hukuman kurungan dalam masa tertentu, maka pemerintah juga harus memikirkan lembaga pemasyarakatan yang sesuai untuk anak dan remaja tersebut. Lembaga pemasyarakatan yang dimaksud harus yang ramah anak serta bisa menumbuhkan sikap hidup yang positif serta membantu anak dan remaja di dalamnya agar siap kembali ke masyarakat.

Perlakuan terhadap anak yang berhadapan dengan hukum perlahan berubah seiring dengan diberlakukannya UU No 11 Tahun 2012 tentang Sistem Peradilan Pidana Anak mulai 31 Juli 2014 lalu. Menandai transformasi perlakuan terhadap ABH tersebut pemerintah pun akan mengubah Lapas Anak menjadi Lembaga Pembinaan Khusus Anak (LPKA). Sistem perlakuan yang ramah anak antara lain akan diaplikasikan seperti pendampingan bagi anak saat mulai ditempatkan di LPKA, pengenalan diri dan lingkungan, program pembinaan, pengasuhan pemasyarakatan hingga mempersiapkan reintegrasi sosial anak. Di Indonesia saat ini terdapat 20 Lapas Anak, dan seluruhnya nanti akan menjalankan sistem baru perlakuan ramah anak. Pemberlakuan UU No 11 Tahun 2012 ini akan lebih mengayomi anak yang bermasalah dengan hukum, dimana akan diterapkannya diversi (pengalihan penyelesaian perkara dari pidana jadi luar pidana) dan keadilan retoratif yaitu penyelesaian perkara yang melibatkan keluarga pelaku, keluarga korban dan masyarakat.

Salah satu bentuk perlakuan yang ramah anak adalah dengan tetap menjamin keberlangsungan pendidikan anak dengan sistem pendidikan khusus Hal ini sesuai dengan 
peraturan tentang sistem pendidikan yang dikhususkan bagi anak usia sekolah melalui Undang - Undang Sistem Peradilan Pidana Anak (UU SPPA). Dalam UU SPPA diatur bahwa setiap Anak dalam proses peradilan pidana berhak memperoleh pendidikan. Karena itu, LPKA wajib menyelenggarakan pendidikan, pelatihan keterampilan, pembinaan, dan pemenuhan hak lain sesuai dengan ketentuan peraturan perundang-undangan. Program pendidikan dan pembinaan ini diawasi oleh Balai Pemasyarakatan ( Cahyaningtyas, I, 2015)

Dalam praktiknya, LPKA bisa melibatkan lembaga pemerintah maupun masyarakat salah satunya dengan melibatkan perguruan tinggi untuk memberikan pendidikan formal dan non formal seperti pelatihan ketrampilan guna memberdayakan anak dan remaja penghuni LPKA.

Pemberdayaan merupakan suatu konsep untuk memberikan tanggungjawab yang lebih besar kepada orang-orang tentang bagaimana melakukan pekerjaan. Pemberdayaan akan berhasil jika dilakukan oleh pengusaha, pemimpin dan kelompok yang dilakukan secara terstruktur dengan membangun budaya kerja yang baik (Purwanto, N., \& Rofiah, C, 2017)

\section{METODE PELAKSANAAN KEGIATAN}

Metode pelaksanaan kegiatan PKM ini berupa pelatihan dan pendampingan kemampuan bidang Desain Grafis serta hasil produk yang bernilai jual. Ada lima bentuk kerja utama yang dilakukan, mulai dari tahap persiapan, tahap pembinaan, tahap pendampingan, tahap pelatihan dan terakhir tahap evaluasi kegiatan.

\section{Tahap Persiapan.}

Tahap persiapan ini dimulai dengan sosialisasi kegiatan PKM dan Program Kecakapan Hidup (Pemaparan oleh Tim Pelaksana) serta dan Fokus Group Discussion (FGD) dengan Mitra I dan Mitra II. Selanjutnya, tim pelaksana merancang bentuk/konsep kegiatan, waktu dan tempat pelaksanaan, tujuan serta manfaat kegiatan hingga kegiatn pendampingan promosi hasil produk program life skill tecnopreneurship bidang Desain Grafis. Tim pendamping juga membuat modul-modul pelatihan yang akan disiapkan sebelum kegiatan pelatihan dimulai. Modul pelatihan dibuat praktis, mudah dimengerti, dilengkapi dengan banyak contoh, dan dapat diterapkan dengan mudah. Adapun 4 modul pelatihan yang akan disiapkan oleh Tim Pelaksana adalah: 1) Pelatihan Desain dan Cetak Undangan, 2) Pelatihan souvenir dengan teknik resin, 3) Pelatihan pembuatan WPAP, dan 4) Pelatihan manajemen usaha dan pemasaran usaha mikro.

\section{Tahap Pembinaan}

Pada tahap ini tim pelaksana melakukan kegiatan Penyuluhan dan Motivasi Technopreneurship Bidang Desain Grafis kepada anak didik LPKA. Tujuannya adalah memberikan gambaran manfaat kepada anak didik pentingnya penguasaan keahlian/keterampilan tertentu sebagai bekal hidup mandiri dan memiliki kemampuan berwirausaha.

\section{Tahap Pelatihan}

Pada tahap ini Tim pelaksana akan memulai kegiatan pelatihan sesuai dengan jadwal yang sudah ditentukan dan disepakati bersama dengan mitra. Adapun kegiatan pelatihan utama yang dilakukan adalah:

- Pelatihan Desain dan Cetak Undangan. Anak didik LPKA akan dipandu dengan modul dan trainer dari tim pelaksana untuk mendesain dan melakukan teknik cetak sederhana.

- Pelatihan souvenir dengan teknik resin. Anak didik LPKA akan dipandu dengan modul dan trainer dari tim pelaksana untuk membuat souvenir (gantungan kunci dan stiker) dengan teknik resin sampai dengan proses packaging.

- Pelatihan pembuatan lukisan WPAP. Anak didik LPKA akan dipandu dengan modul dan trainer dari tim pelaksana untuk membuat lukisan WPAP sampai dengan proses cetak serta 
pembingkaian. WPAP adalah gaya seni pop art modern yang merupakan singkatan dari Wedha's Pop Art Portrait. WPAP adalah karya yang unik dan menarik karena mengubah gambar wajah menjadi berbentuk bidang-bidang yang menggunakan garis yang tegas dan warna yang saling bertabrakan tanpa mengurangi kemiripan dari foto asli melalui penggunaan aplikasi antara lain: Corel Draw, Photoshop, dan Adobe Ilustrator.

- Pelatihan manajemen usaha dan pemasaran usaha mikro. Anak didik LPKA akan dipandu dengan modul dan trainer dari tim pelaksana untuk membuat portofolio usaha kecil, perhitungan keuangan usaha sederhana, teknik packaging yang menarik, dan menggunakan teknik promosi dan pemasaran melalui pemanfaatan sosial media.

\section{Tahap Pendampingan}

Pada tahap ini anak didik LPKA akan diberikan kesempatan berkreasi di bidang Desain Grafis untuk menghasilkan produk-produk yang dapat dipilah untuk dapat dijual atau didisplay pada kegiatan bazar/start up LPKA.

\section{Tahap Evaluasi Kegiatan PKM}

Pada tahap ini pelaksanaan kegiatan evaluasi oleh tim sendiri dan melihat apa saja kendala dan masalah yang muncul di lapangan serta mencari solusi atas permasalahan yang muncul. Pada tahap ini tim pelaksana juga akan memberikan laporan rekomendasi kepada Mitra 1 dan Mitra 2 untuk pelaksanaan berkelanjutan dari program life skill berbasis technopreneurship.

\section{HASIL DAN PEMBAHASAN}

Dari rancangan kegiatan PKM yang telah dipilah menjadi 5 (lima) tahapan, selanjutnya tim pelaksana melakukan kegiatan sesuai dengan jadwal pelaksanaan.

1. Tahap Persiapan.

Pada tahapan ini, tim pelaksana melakukan sosialisasi kegiatan PKM kepada kedua mitra yakni: mitra 1 Bidang Pendidikan dan Pelatihan Keterampilan (Mitra I) dan Bidang Bimbingan dan Pengentasan Anak (Mitra II). Kegiatan sosialisasi ini dilaksanakan pada tanggal 3 Maret 2018 ditujukan untuk menjelaskan bahwa "PKM Program Kecakapan Hidup Berbasis Technopreneurship Bagi Anak Didik Lpka Kelas I Palembang Provinsi Sumatera Selatan dalam Upaya Pembekalan Hidup Mandiri” didanai oleh RistekDikti. Pada kegiatan ini juga disepakati jadwal PKM antara tim pelaksana, Bapak Fahriyuddin Jusep (pimpinan mitra I), dan Bapak Hendri (pimpinan mitra II). Selanjutnya dilakukan pertemuan dengan pimpinan LPKA Kelas I Palembang (Bapak Budi Yuliarno), untuk sosialisasi kegiatan PKM dan persetujuan atas jadwal kegiatan PKM yang telah disusun dengan kedua pihak mitra. Selain itu, pimpinan LPKA Kelas I Palembang Bapak Budi Yuliarno juga menugaskan untuk menyiapkan daftar nama-nama anak didik yang merupakan pihak mitra I dan anak didik mitra II yang akan mengikuti Program PKM.

Sebelum melaksanakan kegiatan pelatihan, tim pelaksana juga membuat pelatihan yang disatukan menjadi buku modul Program Kecakapan Hidup Berbasis Technopreneurship Bagi Anak Didik Lpka Kelas I Palembang Provinsi Sumatera Selatan Dalam Upaya Pembekalan Hidup Mandiri. Modul terdiri dari bagian 1: Souvenir dengan teknik resin (oleh Hendra Rotama), 2: pembuatan WPAP/Line Art (Hendra Rotama) , 3: desain dan cetak undangan (dengan teknik pop art) (Fatmariani), dan 4: manajemen usaha dan pemasaran usaha mikro (Febrianty). Proses pembuatan modul pelatihan diselesaikan dalam waktu lebih kurang 1 bulan, dimulai tanggal $10-31$ Maret 2018 . 


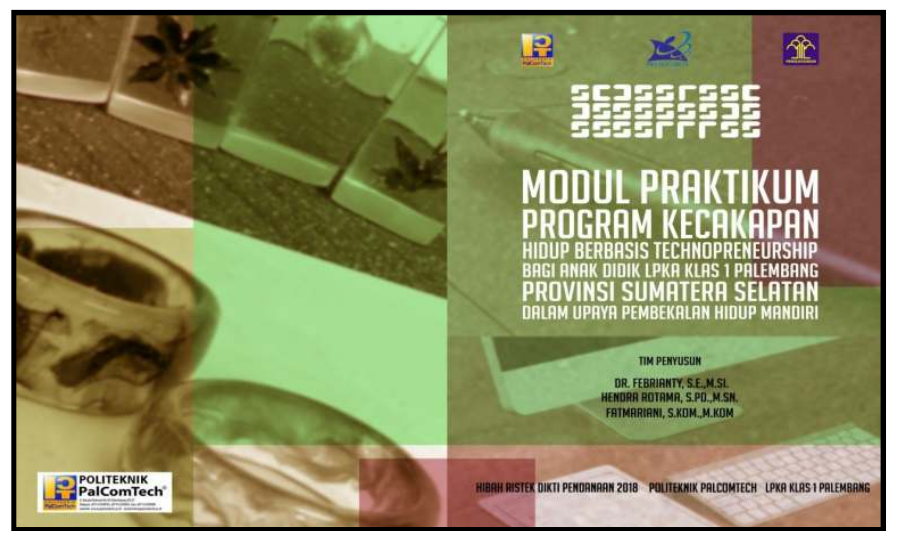

Gambar 1: Buku Modul Praktikum PKM

Selanjutnya dilakukan pemeriksaan dan peng-instal-an program corel draw dan photoshop serta pengecekan komputer yang layak pakai, di laboratorium komputer LPKA Kelas I Palembang yang akan digunakan untuk kegiatan pelatihan. Berikut adalah kegiatan peng-instal-an software di laboratorium komputer LPKA Kelas I Palembang. Pada tahap persiapan juga tim pelaksana mengajak anak didik LPKA Kelas I membuat desain kemasan untuk souvenir yang dihasilkan dari Program PKM, yang disebut "Seni Motif Technopreneurship LPKA Kelas I Palembang”.

Seni motif yang digunakan untuk kemasan souvenir hasil Technopreneurship LPKA Kelas I Palembang yang dapat diaplikasikan dalam berbagai ukuran kemasan dan menjadi ciri khas kemasan souvenir hasil Technopreneurship LPKA Kelas I Palembang. Adapun kemasan kotak tersedia dalam bentuk yang kecil, sedang dan besar. Disamping itu juga tersedia logo dan slogan pemasaran produk (daktelawan.com) hasil karya anak didik LPKA Kelas I Palembang. Selanjutnya, tim pelaksana PKM juga telah mendaftarkan hak cipta pada untuk Seni Motif Technopreneurship LPKA Kelas I Palembang dan Modul Praktikum PKM guna mendapatkan Hak Kekayaan Intelektual.

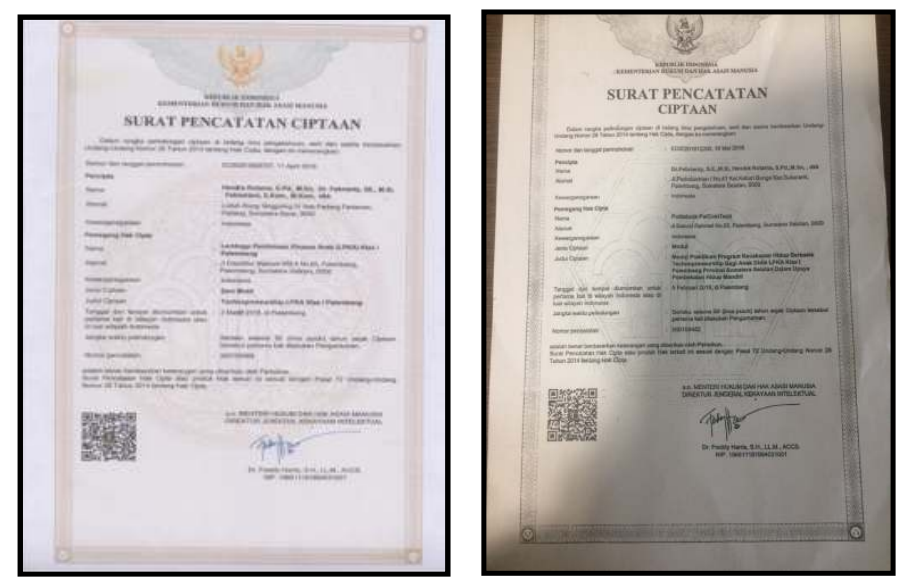

Gambar 2: Sertifikat HKI Seni Motif Technopreneurship dan Modul Praktikum

Kegiatan yang dilakukan tim pelaksana PKM ini mendapat respon yang positif dari berbagai pihak. Hal ini terbukti dari kunjungan yang dilakukan Kepala Divisi Pemasaran Sumtera Selatan Bapak Giri Purbadi, Bc.I.P., S.H, Pelaksana Tugas Direktur Jendral Pemasyarakatan Bapak Dr. Mardjoeki, Bc.I.P., M.Si. dan Duta Besar Denmark ke LPKA. 

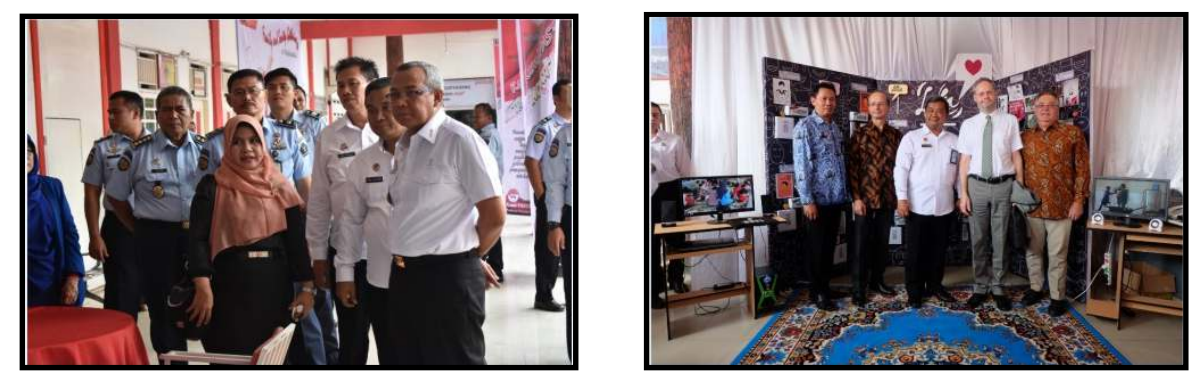

Gambar 3: Kunjungan KadivPas Sumsel, PLT Dirjen Pemasyarakatan, dan serta Duta Besar Denmark

\section{Tahap Pembinaan}

Pada tahap ini tim pelaksana PKM mengadakan kegiatan penyuluhan motivasi technopreneurship Bidang desain Grafis kepada anak didik LPKA Kelas IA Palembang. Tujuannya adalah memotivasi anak didik agar mau mengikuti pelatihan-pelatihan yang akan diadakan. Disamping itu, memberikan gambaran manfaat kepada anak didik pentingnya penguasaan keahlian/keterampilan tertentu sebagai bekal hidup mandiri dan memiliki kemampuan berwirausaha. Kegiatan penyuluhan ini berisi tentang gambaran peluang usaha dan bagaimana wirausaha di bidang desain grafis.
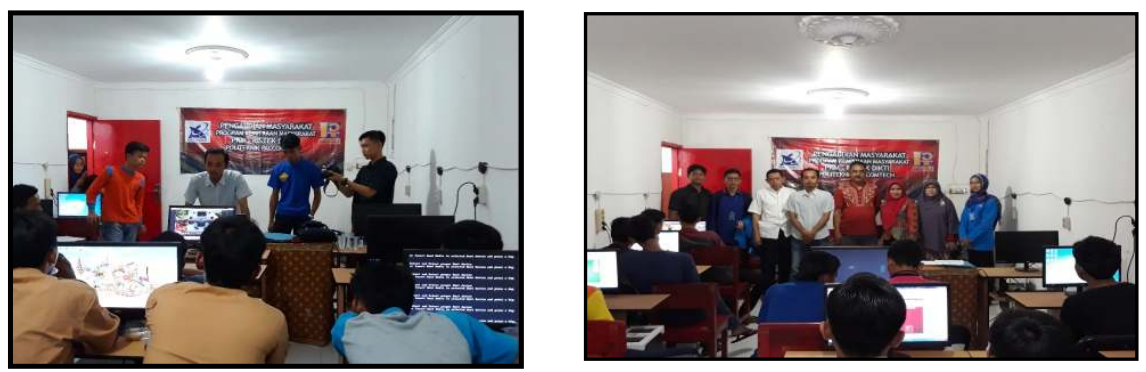

Gambar 3: Foto kegiatan penyuluhan motivasi technopreneurship Bidang desain Grafis kepada anak didik LPKA Kelas I Palembang (14 April 2018)

\section{Tahap Pelatihan}

Tim pelaksana PKM melaksanakan kegiatan pelatihan sesuai dengan jadwal yang sudah ditentukan dan disepakati bersama kedua pihak mitra. Kegiatan pelatihan yang dilakukan yaitu:

a. Pelaksanaan Pelatihan Souvenir dengan teknik resin bagi anak didik LPKA Kelas I Palembang dimulai dari tanggal 11-14 Mei 2018 (selama 4 hari). Berikut ini adalah kegiatan pelatihan souvenir dan hasil dari kegiatan.
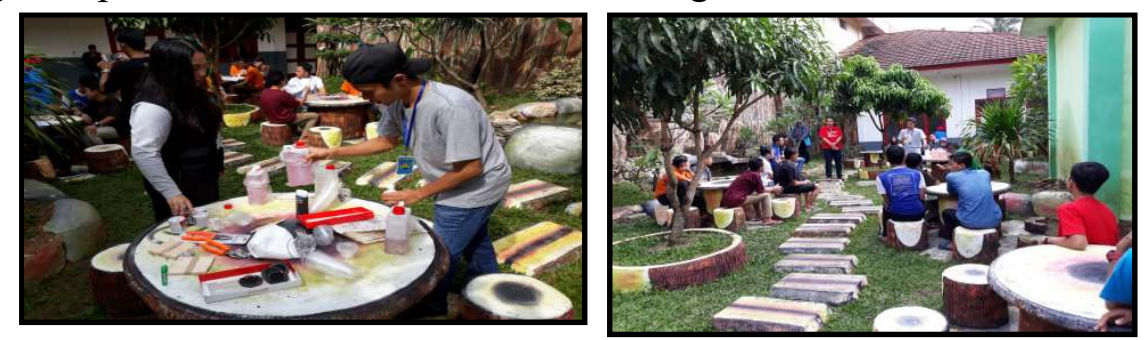

Gambar 4: Foto Pelaksanaan Pelatihan Souvenir dan Hasilnya

b. Pelaksanaan Pelatihan desain dan cetak undangan bagi anak didik LPKA Kelas I Palembang 8-11 Juni 2018 (selama 4 hari). Berikut ini adalah kegiatan pelatihan desain dan cetak undangan dan hasil dari kegiatan. 

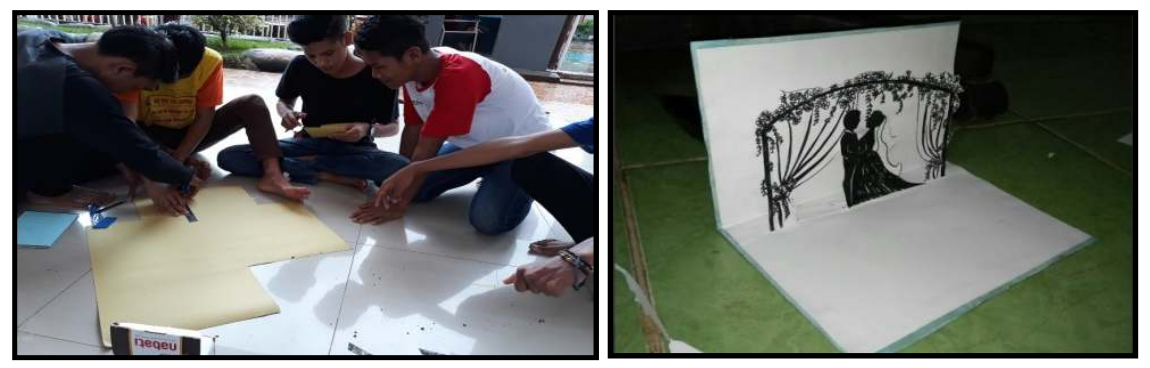

Gambar 5: Foto Pelaksanaan Pelatihan Desain dan Cetak Undangan

c. Pelaksanaan Pelatihan pembuatan WPAP/Line Art bagi anak didik LPKA kelas I Palembang 18-21 Mei 2018 dilengkapi dengan contoh hasil kegiatan.
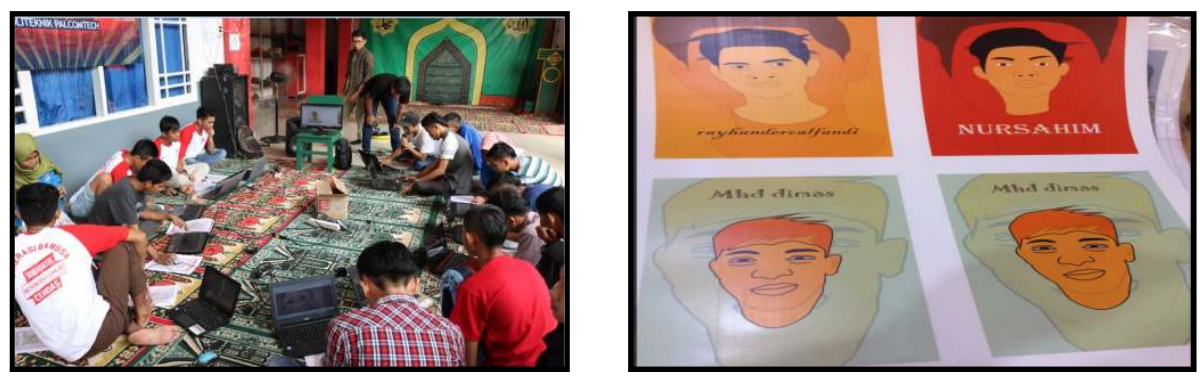

Gambar 6: Foto Pelaksanaan Pelatihan pembuatan WPAP/Line Art

d. Pelaksanaan kegiatan pameran hasil anak didik LPKA Kelas I Palembang yang diselenggarakan selama 3 hari dari tanggal 16-18 April 2018. Sehubungan dengan kegiatan PKM terdapat publikasi di dua koran lokal yakni: Harian Bisnis Sripo dan Tribun Sumsel semua koran tertanggal 16 April 2018.
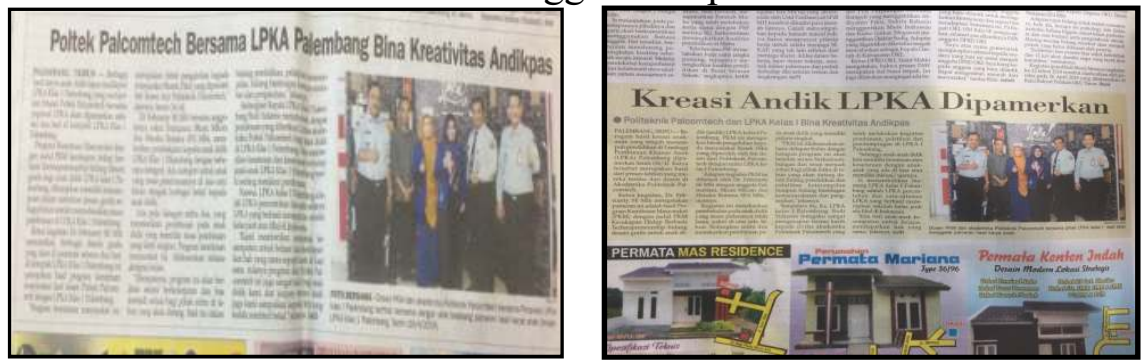

Gambar 7: Publikasi di Koran Harian Bisnis Sripo dan Tribun Sumsel

4. Tahap Pendampingan

a. Pendampingan kegiatan kreatiativitas peserta dan kegiatan bazar/start up LPKA Kelas IA Palembang dari tanggal 10-13 April 2018, mengarahkan anak didik untuk dapat melakukan Setting layout pameran dan dekorasi pameran.
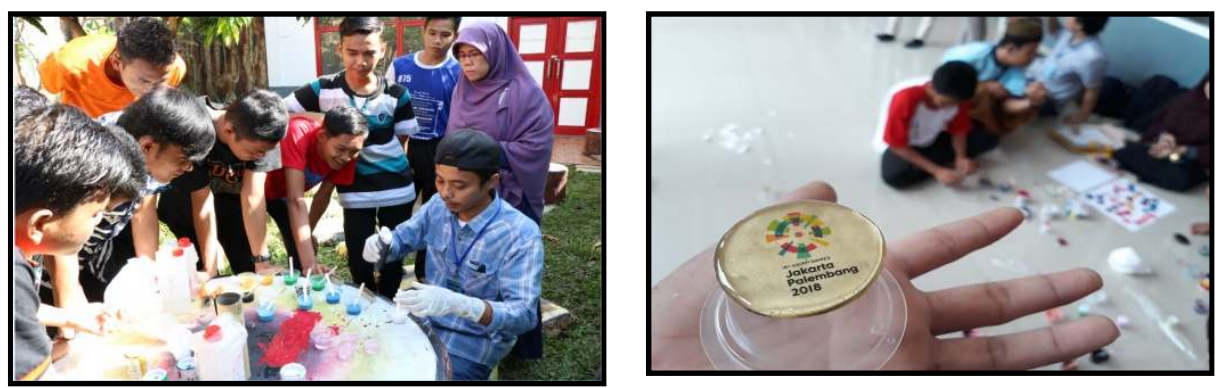

Gambar 8: Foto-foto Pelaksanaan Kegiatan Pendampingan dan hasilnya 
b. Pendampingan bagi anak didik LPKA Kelas I Palembang untuk menyelesaikan hasil karya mereka dilaksanakan selama 4 hari yakni tanggal 23-26 Mei 2018.
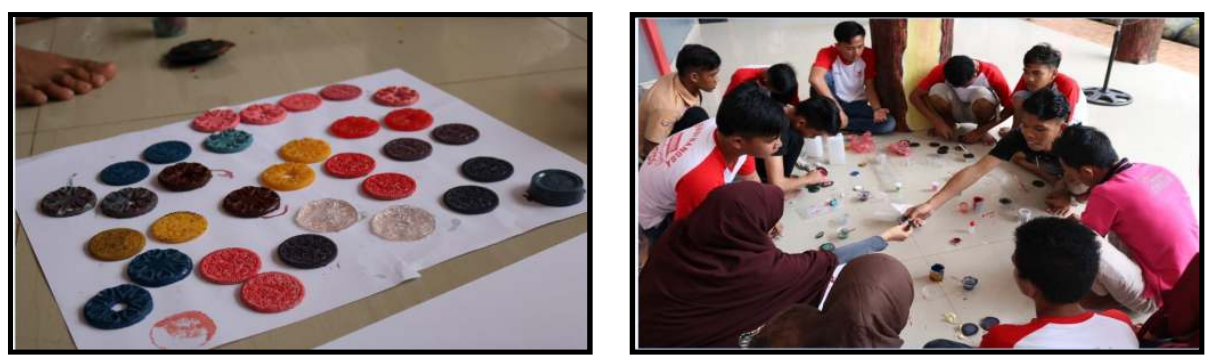

Gambar 9: Foto-foto Pelaksanaan Kegiatan Pendampingan dan Hasilnya

c. Pendampingan bagi anak didik LPKA Kelas I Palembang agar dapat menyelesaikan hasil karyanya selama 2 hari (27-28 Juni 2018)
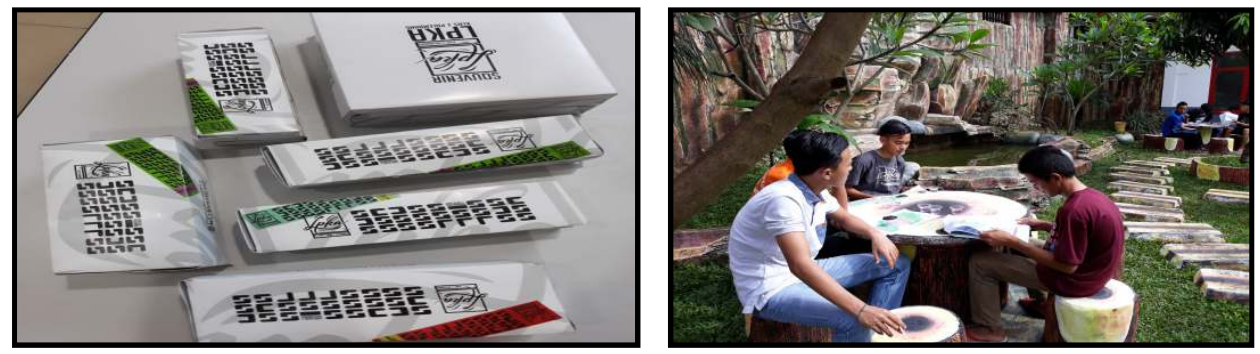

Gambar 13. Foto-foto Pelaksanaan Kegiatan Pendampingan dan Hasilnya

\section{Tahap Evaluasi Kegiatan PKM}

Tim pelaksana pada tahap evaluasi kegiatan PKM melakukan penyebaran kuesioner dan pengolahan hasil kuesioner, yang dilaksanakan tanggal 25-26 Juni 2018, sebagai bentuk untuk mengetahui umpan balik dan capaian hasil dari masing-masing kegiatan pelatihan yang telah diadakan oleh Tim Pelaksana PKM, yang selanjutnya disajikan dalam bentuk laporan evaluasi PKM. Selanjutnya dilakukan diskusi dengan anggota tim mengenai pembuatan laporan Rekomendasi program ke mitra LPKA Kelas I Palembang (disertai dengan menyerahkan video tutorial kegiatan pelatihan PKM technopreneurship).

Berdasarkan uraian Hasil kegiatan PKM Program Kecakapan Hidup Berbasis Technopreneurship Bagi Anak Didik LPKA Klas I Palembang Provinsi Sumatera Selatan dalam Upaya Pembekalan Hidup Mandiri diatas maka capaian yang dihasilkan adalah sebagai berikut:

1. Berdasarkan hasil evaluasi melalui kuesioner umpan balik terjadi peningkatan daya saing dengan capaian besar peningkatan kualitas technopreneurship 60\%, yang dapat dilihat melalui hasi karya anak didik (produk bernilai jual) dan kemampuan mengadakan Bazar/start up LPKA.

2. Dengan terlaksananya kegiatan penyuluhan motivasi technopreneurship bidang desain grafis, pelatihan souvenir dengan teknik resin, pelatihan desain dan cetak undangan, pelatihan pembuatan WPAP/Line Art, dan pelatihan manajemen usaha dan pemasaran usaha mikro serta kegiatan pendampingan oleh tim pelaksana PKM telah dapat memberikan kemampuan penerapan IPTEK bidang desain grafis dengan capaian sebesar 78\% (berdasarkan hasil evaluasi melalui kuesioner umpan balik). 
3. Berdasarkan hasil evaluasi juga didapatkan peningkatan rasa percaya diri anak didik dan kemandirian anak didik dengan keterampilan khusus yang dimiliki serta semangat kewirausahaan bidang Desain Grafis dengan capaian 64\%.

4. Tersedia beberapa hasil karya dari anak didik yang bernilai jual yang dijual di ruang pameran LPKA Kelas I Palembang.

5. Tersedia juga modul keterampilan bidang Desain Grafis, draft Buku ber ISBN, Publikasi ilmiah pada Jurnal ber ISSN/Prosiding, dan Publikasi pada media masa repocitory di Politeknik Palcomtech.

\section{E. PENUTUP}

Dari hasil kegiatan yang telah disampaikan diatas, maka dapat disimpulkan bahwa kegiatan pelatihan dan pendampingan yang dilakukan tim penulis selama 8 (delapan) bulan telah berjalan dengan baik dan mendapat respon positif dari peserta binaan. Kegiatan PKM yang dilakukan penulis adalah sebuah awal dan diharapkan dapat ditindaklanjuti oleh kedua mitra sebagai bentuk keberlanjutan dari program life skill berbasis technopreneurship, antara lain dengan: 1) melakukan pelatihan mandiri dengan memanfaatkan tutorial pelatihan bidang desain grafis yang telah disajikan/dibuat oleh tim pelaksana PKM, 2) memanfaatkan ruang pameran yang telah ada sebagai zona kreativitas dan entrepreneurship di LPKA Kelas I Palembang, 3) kontinuitas pemanfaatan laboratorium komputer LPKA Kelas I Palembang melalui kegiatan-kegiatan motivasi technopreneurship, 4) pengembangan sosial media atau website promosi dan pemasaran produk hasil karya anak didik LPKA Kelas I Palembang, 5) melakukan kaderisasi anak didik yang akan menjadi tenaga ahli selanjutnya.

\section{DAFTAR PUSTAKA}

Atikasuri, M., Mediani, H. S., \& Fitria, N. (2018). Tingkat Kecemasan pada Andikpas Usia 14-18 Tahun Menjelang Bebas di Lembaga Pembinaan Khusus Anak Kelas II. Journal of Nursing Care, 1(1), 78.

Cahyaningtyas, I. (2015). Pembinaan Anak Pidana Di Lembaga Pembinaan Khusus Anak Dalam Perspektif Restorative Justice. Notarius, 8(2), 342-353.

Data LPKA. 2016. Jumlah Anak Didik LPKA Beserta Jenis Kejahatan Tahun 2016.

Departemen Pendidikan Nasional, 2004, Paket Pelatihan Diklat Kurikulum Berbasis Komptensi. Broad Based Education (BBE) \& Life Skill.

Purwanto, N., \& Rofiah, C. (2017). Pemberdayaan Usaha Ekonomi Produktif Bagi Masyarakat Di Kecamatan Ploso Kabupaten Jombang. Comvice: Journal of Community Service, 1(1), 29-32.

Undang-undang No. 12 Tahun 1995 tentang Pemasyarakatan. 